policy, in light of the uncertainty surrounding the complex mechanism linking long-term knowledge activities at the universities and industrial commercialization. Of particular note: the Japanese business environment is largely under the dominance of global enterprises typically based in the United States. It is becoming apparent that universities will have to struggle and fight to gain their financial autonomy and, ultimately, define their new identity.

DOI: http://dx.doi.org/ıo.6oI7/ihe.20I9.96.10779

\section{The Recent Crisis in South African Universities}

\section{Jonathan Jansen and Cyrill Walters}

Jonathan Jansen is Distinguished Professor of education at Stellenbosch University in the Western Cape, South Africa. E-mail: jonathanjansen@sun.ac.za. Cyrill Walters is postdoctoral fellow at Stellenbosch University.E-mail: cyrillwalters@sun.ac.za.

Tn 2015-2016, South African universities experienced the 1 most intense and violent student protests in a century of higher education. Most analysts attribute the widespread campus protests to two factors: the alienating cultures of historically white universities, associated with the movement labelled \#RhodesMustFall (\#RMF); and the discriminatory cost of higher education, which gave rise to a movement known as \#FeesMustFall (\#FMF).

The \#RMF protests started in March 2015 at South Africa's premier institution of higher education, the University of Cape Town (UCT), when undergraduate student Chumani Maxwele set off a wave of protest by throwing human excrement on a statue of the nineteenth-century British colonialist Cecil John Rhodes-a statue that paid tribute to a man who came to embody the dreams, aspirations, and superiority complex of imperial Britain, leading to the colonial dispossession and oppression of Africans. Rhodes was a British imperialist who acquired vast mineral wealth and created the colony of Rhodesia. It was the same Rhodes who provided funding for the creation of UCT as well as Rhodes University in the Eastern Cape. After the \#RMF protesters succeeded in having the statue of Rhodes removed from campus, the movement's demands expanded further to the transformation of institutional symbolism (such as artworks), the hiring of more black professors, and what was called "the decolonization of curriculum."
The \#FMF revolt against high tuition fees started in October 2015 at another major research institution, the University of the Witwatersrand, in Johannesburg. Students protested against the growing costs of tuition, which limited access to higher education and left graduates with considerable debt. The students eventually "won" their case as the besieged, corrupt, and populist President of South Africa unexpectedly declared-against the advice of two official commissions - that higher education would be free for poor students.

\section{The Costs of the Student Revolt}

These two streams of "fallist" protests (Rhodes and fees) merged into a powerful student movement that gave a sense of urgency to the transformation of the seven historically white universities and to the opening up of access to higher education for poor students, especially in the eight historically black universities. But the protests came at a huge cost to South African institutions. Fires raged across campuses as buildings were set alight, including libraries, computer centers, student residences, and administration buildings. Estimates of the damage run from R 800 million to R 2 billion (\$55 million to \$I37 million). Weeks of lecturing time were lost at several universities, leading to emergency arrangements for teaching and tight security for examinations. Staff and students were traumatized by the intensity of the protests, which included constant disruptions of classes and much physical intimidation, as well as by the actions of the police and security forces called in to contain the disturbances.

There were many personal tragedies. A petrol bomb was lobbed through the window of a vice-chancellor's office. A tragic suicide of a leading medical scientist grabbed national attention. This professor was also the first black dean of his faculty of health sciences and his death was attributed by his family to the personal trauma he suffered at the hands of protesting students, who occupied his office and insulted him. At another university, a worker died as a result of an asthma attack after students discharged a fire extinguisher in an enclosed space. A policeman and security guard were trapped inside a booth when it was set alight by students. At UCT, one security guard was severely beaten with an iron rod, and another's skull was fractured when a protester dropped a brick on his head from four floors above.

At the major universities, international contracts and much-needed revenue were lost as students from universities abroad cancelled their study visits to South African campuses. Leading academics, including vice-chancellors, went into retirement or took jobs at universities abroad. And relationships among academics; between academics 
and management; and between students, academic staff, and the university leadership, were fundamentally changed in the wake of these violent and prolonged protests.

\section{Consequences of the Protests for Academic Culture(s)}

There is no doubt that the protests raised crucial issues of financial access and racial inclusion in post-apartheid universities. In this context, the protests should be seen as a gift to society and a much-needed push toward transforming hard-to-change institutions. But what else was lost in the fire? The Academy of Science of South Africa launched a seminar forum to deliberate on the way in which campus cultures changed after the $2015-2016$ protests. From these deliberations, it became clear that all of the public universities were much changed. At historically black campuses, violence and disruptions continued from one week to the next. At some historically white campuses, there were reported incidents of whites being excluded from public events or being asked to leave certain lectures. Works of art have been vandalized and covered up in some cases, including the

\section{The \#FMF revolt against high tuition fees started in October 2015 at another major research institution, the Univer- sity of the Witwatersrand.}

works of progressive and black artists; such acts have raised the alarm of creeping censorship on university campuses. The Danish journalist Flemming Rose was disinvited from, ironically, the Academic Freedom Lecture at the University of Cape Town; Rose drew controversy by having published cartoons of the Prophet Mohammed in Denmark some Io years ago. And at one Johannesburg university, academic teaching staff have to report on how much they have done to "decolonize" their curricula.

The physical damage to university buildings will be repaired and rebuilt over time. Much harder will be dealing with the psychological and emotional trauma that the protests left in their wake. But the more serious consequences of the 20I5-20I6 student protest movement include the long-term threat to the very idea of a university as a place for the free expression of ideas; a space in which academic functions like teaching, learning, research, and public commitments can proceed without frequent and violent interruptions; and a forum in which knowledge transaction remains open ended and inclusive rather than subject to the ideological dictates of any political movement or passing fad.

\section{Broader Implications of the South African University CRISIS}

South Africa is not exceptional. Recent research identifies the key reasons for the demise of once great African universities as being political interference, financial crises, and chronic disruption to the academic project of the university. While most South African institutions seem to have entered a period of uneasy stability since the $2015-2016$ protests, it is not at all clear whether the country's 26 public universities will be able to rebuild the social, intellectual, and cultural capabilities that distinguished them from other kinds of public entities.

These wide-scale student protests also have direct implications for the Southern African region and the continent as a whole. Middle-class African students from outside South Africa see post-apartheid tertiary institutions as relatively stable and offering, through the local elite research universities, a nearby and more affordable option for quality higher education than Western Europe or the United States. In the same way, African scholars consider South Africa's top universities as places where they may pursue their own academic careers. It is quite likely that this inflow of academic talent from the continent has also been threatened as a consequence of the $2015-2016$ protest movement. Time will tell.

DOI: http://dx.doi.org/Io.6oI7/ihe.20I9.96.10780

\section{Student Pathways in South Africa}

\section{Rebecca SCHENDEL}

Rebecca Schendel is lecturer in education and international development at the Institute of Education, University College London, UK. Email: r.schendel@ucl.ac.uk.

The content of this article represents the work of the Pathways project, a collaborative effort that will soon be published as Higher Education Pathways: South African Undergraduate Education and the Public Good (an African Minds publication).

$\mathrm{M}$ uch is expected of higher education systems around the world; individual families pin their hopes on the 